This document is the accepted manuscript version of the following article: Pisoni, S., Fu, F., Feurer, T., Makha, M., Bissig, B., Nishiwaki, S., ... Buecheler, S. (2017). Flexible NIR-transparent perovskite solar cells for all-thin-film tandem photovoltaic devices. Journal of Materials Chemistry A, 5(26), 13639-13647. http://doi.org/10.1039/c7ta04225f

\title{
Flexible NIR-Transparent Perovskite Solar Cells for All-Thin-Film Tandem Photovoltaic Devices
}

\author{
Stefano Pisoni, ${ }^{* a}$ Fan Fu, ${ }^{\text {a }}$ Thomas Feurer, ${ }^{a}$ Mohammed Makha, ${ }^{b}$ Benjamin Bissig, ${ }^{a}$ Shiro \\ Nishiwaki, ${ }^{\mathrm{a}}$ Ayodhya N. Tiwari ${ }^{\mathrm{a}}$ and Stephan Buecheler*a

\footnotetext{
${ }^{a}$ Laboratory for Thin Films and Photovoltaics, Empa - Swiss Federal Laboratories for Materials Science and Technology, Ueberlandstrasse 129, 8600 Duebendorf, Switzerland.

${ }^{\mathrm{b}}$ Laboratory for Functional Polymers, Empa - Swiss Federal Laboratories for Materials Science and Technology, Ueberlandstrasse 129, 8600 Duebendorf, Switzerland

*E-mail: stefano.pisoni@empa.ch, stephan.buecheler@empa.ch
}

\begin{abstract}
The possibility to grow perovskite solar cells on flexible substrates can be seen as an exciting opportunity, allowing high throughput roll-to-roll manufacturing with a low embodied energy, and creating new applications in buildings, vehicles, portable electronics and internet-of-things based devices. Flexible perovskite solar cells have previously been developed on polymer substrates such as polyethylene terephthalate (PET) or polyethylene naphthalate (PEN) which are vulnerable to the ingress of moisture. Here we report development of flexible perovskite solar cells grown on a typical transparent front sheet which is generally used to encapsulate flexible $\mathrm{Cu}(\mathrm{In}, \mathrm{Ga}) \mathrm{Se}_{2}(\mathrm{CIGS})$ solar cells. This type of substrate displays ultra-low water vapor transmission rate and good UV blocking properties. Perovskite solar cells, grown on such flexible front sheets coated with a highly transparent conducting $\mathrm{ZnO}: \mathrm{Al}(\mathrm{AZO})$ electrode and vacuum processed $\mathrm{ZnO} / \mathrm{C} 60$ electron transport multilayer, yield $13.2 \%$ and $10.9 \%$ stabilized efficiencies for areas of $0.15 \mathrm{~cm}^{2}$ and $1.03 \mathrm{~cm}^{2}$, respectively. The substitution of an opaque rear contact with the transparent electrode enables the realization of flexible NIR-transparent perovskite solar cells with efficiencies above $12 \%$. These devices display an average transmittance of $78 \%$ between
\end{abstract}


800-1000 nm and enable the development of 4-terminal polycrystalline all-thin-film flexible perovskite/CIGS tandem devices. In a first proof of concept $18.2 \%$ efficiency is obtained.

\section{Introduction}

Flexible lightweight photovoltaic devices can find applications in numerous fields from building and transport integrated photovoltaics (PV) to portable and indoor electronics. Furthermore, benefits from utilizing high throughput roll-to-roll manufacturing can be envisaged leading to low production costs. ${ }^{1}$ While flexible $\mathrm{Cu}(\mathrm{In}, \mathrm{Ga}) \mathrm{Se}_{2}$ (CIGS) solar cells with efficiencies above $20 \%$ have already been developed on polyimide, ${ }^{2}$ several companies have entered into roll-to-roll manufacturing of flexible CIGS solar modules. ${ }^{1}$

Halide perovskite solar cells on glass substrates have rapidly achieved impressive efficiencies above $22 \%$ over the past few years, and the possibility to deposit highly crystalline and uniform perovskite films with low temperature processes (below $150^{\circ} \mathrm{C}$ ) has enabled the realization of flexible solar cells on temperature-sensitive polymer foils. $\frac{3-6}{}$ Flexible perovskite solar cells with efficiencies as high as $17.3 \%$ (on indium tin oxide (ITO)/ polyethylene naphthalate (PEN) substrates) and superior stability against bending deformation have already been reported in literature, ${ }^{7}$ demonstrating the high potential for polycrystalline thin film flexible perovskite photovoltaic devices. However, it should be noted that this high efficiency is obtained on very small active areas of $0.02 \mathrm{~cm}^{2}$. Generally, films of polyethylene terephthalate (PET) and PEN are used as transparent substrates for flexible perovskite solar cells. $\frac{8-18}{}$ However, these polymer substrates have a water-vapor transmission rate (WVTR) which is too high meaning that additional encapsulation material would be required. ${ }^{6}$ Considering that moisture and oxygen have detrimental effects on the stability and performances of halide-based perovskite solar cells, $\frac{19}{}$ alternative flexible substrates with better barrier properties against moisture ingress and UV radiation are desired. 
The most efficient flexible perovskite solar cells reported in literature are developed onto ITOcoated plastic substrates (PEN or PET),$\frac{13,17}{17}$ however, Al-doped ZnO (AZO) is a promising and interesting alternative anode for perovskite solar cells due to its low-cost and high transmittance in the near-infrared (NIR) region. Only a few papers have reported highly NIR-transparent AZO as the transparent conducting oxide (TCO) anode for superstrate configuration perovskite solar cells. Zhao et al. reported a $12.6 \%$ efficiency AZO-based perovskite solar cell with a better thermal stability compared to devices based on undoped $\mathrm{ZnO} .^{\underline{20}}$ Roose et al. demonstrated a stabilized $12.5 \%$ efficiency perovskite solar cell based on an AZO TCO anode coated with a mesoporous $\mathrm{SnO}_{2}$ electron transport layer (ETL). ${ }^{21}$ Roldan-Carmona et al. have reported flexible perovskite solar cells based on an AZO anode layer (specifically a multilayer AZO/Ag/AZO) achieving an efficiency of $7 \% . \underline{22}$ These results suggest the promising potential of NIR-transparent high efficiency flexible perovskite solar cells on $\mathrm{Al}$-doped $\mathrm{ZnO}$ for tandem device configuration for utilization of a wider range of the solar spectrum. In order to achieve high efficiency a highbandgap solar cell is combined (stacked) on another solar cell with a low band-gap absorber. ${ }^{23}$ Organic-inorganic hybrid lead halide perovskite solar cells of $1.6 \mathrm{eV}$ energy bandgap are suitable as top cells for tandem applications with a silicon or CIGS bottom cells. ${ }^{23-35}$ In fact, 4-terminal perovskite/CIGS tandem solar cells with efficiencies of up to $22.1 \%$ have already been achieved on glass substrates. $\frac{35}{}$

However, for the development of lightweight flexible tandem solar devices the heavy rigid glass substrate should be substituted by a thinner plastic foil.

Here we report the development of flexible perovskite solar cells on transparent plastic films, which display low WVTR and high UV filtering properties due to the coating applied on them. With gold rear contacts, $13.2 \%$ steady-state efficiency is achieved using AZO as TCO anode and electron transport multilayer consisting of sputtered $\mathrm{ZnO}$ and evaporated $\mathrm{C} 60$. Because of the 
large area uniformity of the vacuum-based deposition processes, we are able to achieve $10.9 \%$ efficiency flexible perovskite solar cell of $1.03 \mathrm{~cm}^{2}$ area. Furthermore, we have developed NIRtransparent flexible perovskite solar cell with steady-state efficiency of $12.2 \%$ and an average transmittance of $78 \%$ between $800-1000 \mathrm{~nm}$. By stacking such a flexible perovskite cell on top of flexible CIGS, $18.2 \%$ efficiency has been achieved in 4-terminal configuration.

\section{Results and discussion}

Fig. 1a shows a photograph of the flexible substrate used in this work. This commercially available foil is commonly used as a front encapsulant for flexible CIGS solar modules and it exhibits, because of certain coatings, a higher transmittance and orders of magnitude lower WVTR values with respect to uncoated high quality PET and PEN flexible substrates. The optical properties of the flexible substrate, with and without AZO film, are measured by UV-vis-NIR spectroscopy (Fig. 1b). The flexible substrate displays an average absorptance below $0.5 \%$ (between 450-1500nm), and when coated by the AZO layer the absorptance stays lower than $4 \%$ in the whole visible region, proving the suitability of this layer as a promising transparent electrode. The $400 \mathrm{~nm}$ AZO layer exhibits a carrier density of $2.9 \times 10^{20} \mathrm{~cm}^{-3}$ and a carrier mobility of $19.9 \mathrm{~cm}^{2} \mathrm{~V}^{-1} \mathrm{~s}^{-1}$, as determined by Hall measurements (Fig. 1b). Fig. 1c and d show the atomic force microscopy (AFM) measured topographies of the flexible substrate with and without the sputtered AZO layer, respectively. Except for the presence of few $\sim 100 \mathrm{~nm}$ high spikes, the AFM measurements display reasonably flat surfaces. The roughness of the flexible substrate is $7.4 \mathrm{~nm}$ (root mean square, RMS), which increases to $10.4 \mathrm{~nm}$ after deposition of the AZO layer. A smooth surface is essential for growing high quality perovskite films and forming well-defined interfaces with the electron- and hole-transport layers (HTLs), avoiding any direct

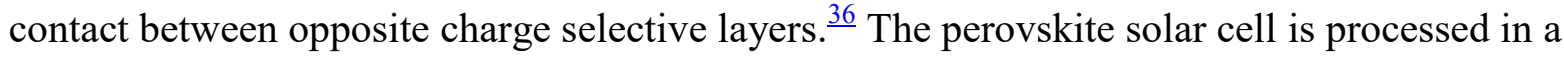


traditional planar heterojunction configuration. On top of the $400 \mathrm{~nm}$-thick AZO TCO, a thin layer $(\sim 50 \mathrm{~nm})$ of unintentionally doped $\mathrm{ZnO}$ is deposited by radio-frequency magnetron sputtering. The use of $\mathrm{ZnO}$ on top of $\mathrm{AZO}$ and below the organic ETL is needed to achieve a favorable cascade conduction band structure which minimizes interfacial charge recombination and facilitates electron transfer. It has been observed that a thin layer of [6,6]-phenyl-C61-butyric acid methyl ester (PCBM) deposited by spin coating helps to obtain a uniform and compact perovskite layer and eliminate $J-V$ hysteresis. ${ }^{24}$ Considering the importance of having conformal coverage of the organic layer over $\mathrm{ZnO}$, it is pivotal to find an alternative to the spin coated thin

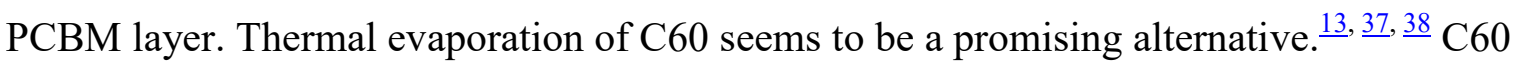
displays a much higher electron mobility $\left(1.6 \mathrm{~cm}^{2} \mathrm{~V} \mathrm{~s}^{-1}\right)$ and conductivity $\left(2.3 \times 10^{-3} \mathrm{~S} \mathrm{~cm}^{-1}\right)$ than $\operatorname{PCBM}\left(6.1 \times 10^{-2} \mathrm{~cm}^{2} \mathrm{~V} \mathrm{~s}^{-1}\right.$ and $3.2 \times 10^{-4} \mathrm{~S} \mathrm{~cm}^{-1}$, respectively), because of a more dense molecular packing which facilitates intermolecular charge transport. $\frac{39}{}$ In addition, C60 can be grown by thermal evaporation allowing a uniformly thick coverage over larger device areas. Furthermore, similar to PCBM, a thin C60 organic layer enables efficient and hysteresis-free planar heterojunction perovskite solar cells. This is owed to the improved charge extraction, which prevents charge accumulation at the perovskite/ETL interface, one possible origin of hysteresis. $\underline{13}$,

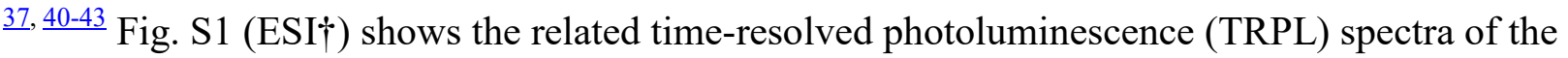
two device structures. In case of the C60 interlayer an additional fast decay is observed indicating a faster electron-transfer process, in agreement with other studies. $\stackrel{4}{4} \underline{41}, \underline{44}, \underline{45}$ In the following, we compare the efficiencies of flexible perovskite solar cells based on spin coated PCBM and thermally evaporated C60. Five different concentrations of PCBM in chlorobenzene $\left(20,15,10,5\right.$ and $\left.2.5 \mathrm{mg} \mathrm{mL}^{-1}\right)$ and three different thicknesses of thermally evaporated C60 (10, 7.5 and $5 \mathrm{~nm})$ were investigated. As shown in Fig. 2a, the optimal PCBM concentration is $10 \mathrm{mg} \mathrm{mL}^{-1}$, which corresponds to a $\sim 30 \mathrm{~nm}$ thick PCBM layer, while in case of 
evaporated C60 efficiencies above 10\% are achieved for all investigated thicknesses. The highest efficiency is obtained for C60 layer with $7.5 \mathrm{~nm}$. Fig. S2 shows the related comparison of mean values and standard deviations.

Fig. S3a and b (see ESI†े) display a comparison of the most representative current-voltage characteristics for different concentrations and thicknesses of PCBM and C60 ETL, respectively. The thickness of the electron transport layer plays a major role in the device performances, $, \frac{13}{,}, \underline{3}$ a too thin ETL results in lower fill factor $(\mathrm{FF})$ and short-circuit current ( $\mathrm{Jsc})$, indicative of a barrier for photocurrent, as a result of incomplete coverage of the $\mathrm{ZnO}$ surface. On the other hand, a too thick ETL will hinder optimal electron transport due to possible charge carrier recombination losses and unfavorable band alignment, resulting in lower fill factor values. Since the carriers generated in the electron selective layer do not contribute to the photocurrent, a thin and uniform interface layer is preferred.

When comparing the optimal values for PCBM concentration and C60 thickness, we observe a better reproducibility and higher average efficiency for $7.5 \mathrm{~nm}$ of thermally evaporated C60. The poor reproducibility of PCBM-based devices in this study most probably originates from nonuniform coverage over larger areas. Fig. $2 \mathrm{~b}$ and $\mathrm{c}$ show the AFM images of the $\mathrm{ZnO} / \mathrm{AZO} /$ front sheet coated with PCBM and C60. Deposition of PCBM by spin coating enables a general smoothening of the $\mathrm{ZnO}$ surface, resulting in a lower roughness (RMS: $5.7 \mathrm{~nm}$ ) with respect to the bare ZnO surface (RMS: $10.9 \mathrm{~nm}$ )(see Fig. S4a and b, ESI†े). Nevertheless, SEM micrographs reveal that some regions of the $\mathrm{ZnO}$ surface are not perfectly covered by the PCBM layer (see Fig. S4c and d, ESI†).

When $\mathrm{C} 60$ is thermally evaporated onto $\mathrm{ZnO}$, the surface roughness remains unchanged (RMS: $11.5 \mathrm{~nm}$ ). A slightly smaller optical absorptance in the substrate/TCO/ETL layer stack is observed in case of C60 as electron transport layer (Fig. S5 (ESI†)). 
Fig. $2 \mathrm{~d}$ and e show morphology of $\mathrm{PbI}_{2}$ on top of PCBM and C60, respectively. According to literature, ${ }^{46}$ evaporated lead iodide forms a compact layer on top of amorphous films like PCBM or $\mathrm{C} 60$. We observe a slightly more compact $\mathrm{PbI}_{2}$ layer on top of PCBM than on $\mathrm{C} 60$, which may be attributed to the different roughness of the surface on which lead iodide is deposited. In both cases, regardless of the slightly different lead iodide film morphologies, after methylammonium iodide spin coating, a compact and uniformly thick perovskite layer is obtained (see Fig. S6, ESI†). A dense lead iodide precursor layer hinders a full conversion to perovskite (see Fig. S7, ESI†) leaving a certain amount of unreacted lead iodide, which is believed to be beneficial for device performances. ${ }^{44,}, 47,48$ The resulting perovskite layer is approximately $280 \mathrm{~nm}$ thick as measured by SEM.. Spiro-OMeTAD is used as hole transport layer (HTL) and the device is completed with $50 \mathrm{~nm}$ of evaporated gold. Due to superior reproducibility the combination of $50 \mathrm{~nm}$ rf-sputtered $\mathrm{ZnO}$ with $7.5 \mathrm{~nm}$ thermally evaporated C60 bi-layer was selected as electron transport material for the development of flexible NIR transparent perovskite solar cells.

Fig. 3 shows the schematic configuration of the device and the photovoltaic characteristics of the champion perovskite solar cell grown on the flexible substrate. The solar cell is not encapsulated and the measurements were done in ambient air with relative humidity of $50 \%$. From the currentvoltage characteristics (Fig. 3b) only a negligible hysteresis is observed between forward (-0.1 V to $1.4 \mathrm{~V})$ and backward $(1.4 \mathrm{~V}$ to $-0.1 \mathrm{~V})$ measurements.

Fig. $3 \mathrm{c}$ shows the measurement of maximum power point (MPP) under continuous illumination to determine the power conversion efficiency at operating conditions. The cell reaches a steadystate efficiency ( $\eta$ ) of $13.2 \%, J_{\mathrm{MPP}}$ of $15.7 \mathrm{~mA} / \mathrm{cm}^{2}$ and $V_{\mathrm{MPP}}$ of $0.84 \mathrm{~V}$. The $J-V$ characteristics of the perovskite solar cell with an area of $0.15 \mathrm{~cm}^{2}$ show a $V_{\mathrm{OC}}$ of $1.06 \mathrm{~V}, J_{\mathrm{sc}}$ of $17.8 \mathrm{~mA} / \mathrm{cm}^{2}$, and a FF of $68.5 \%$, yielding a power conversion efficiency of $13 \%$ measured in forward direction, 
while a $V_{\mathrm{OC}}$ of $1.05 \mathrm{~V}, J \mathrm{sc}$ of $17.4 \mathrm{~mA} / \mathrm{cm}^{2}, \mathrm{FF}$ of $69.8 \%$, yielding an efficiency of $12.8 \%$ when measured in backward direction. As shown in Fig. 3, the $J_{\mathrm{SC}}$ value measured under solar simulator is comparable to the one obtained by integrating the absolute EQE over the AM1.5G spectrum. Fig. 3e shows a histogram of efficiencies obtained from more than 30 flexible perovskite solar cells grown on the bendable encapsulation front sheet. Fig. 4a and $\mathrm{b}$ show the photograph and the current-voltage characteristics of a flexible perovskite device with an area of $1.03 \mathrm{~cm}^{2}$. The device displays a $V_{\mathrm{OC}}$ of $1.0 \mathrm{~V}, J_{\mathrm{sc}}$ of $17.3 \mathrm{~mA} / \mathrm{cm}^{2}, \mathrm{FF}$ of $63 \%$, yielding an efficiency of $10.9 \%$ measured in forward direction, and a $V_{\mathrm{OC}}$ of $1.0 \mathrm{~V}, J \mathrm{sc}$ of $17.2 \mathrm{~mA} / \mathrm{cm}^{2}, \mathrm{FF}$ of $63.3 \%$, yielding an efficiency of $10.8 \%$ when measured in backward direction. The cell reaches a steady-state efficiency of $10.9 \%, J_{\mathrm{MPP}}$ of $15.3 \mathrm{~mA} / \mathrm{cm}^{2}$ and $V_{\mathrm{MPP}}$ of $0.72 \mathrm{~V}$ (Fig. 4c). As shown in Fig. 4d, the $J_{\mathrm{SC}}$ value, obtained by integrating the EQE over the AM1.5G spectrum, is $17.3 \mathrm{~mA} / \mathrm{cm}^{2}$.

Bending tests are carried out to verify the mechanical stability of the devices. Fig. S8a (ESI $\dagger$ ) shows the efficiency measured after one bending cycle at six different radii of curvature (flat, 15, $10,8,6$ and $4 \mathrm{~mm}$ ). The device exhibits good mechanical stability, as also reported in literature,, $\underline{11}, \underline{14}, \underline{16}, \underline{49}, \underline{50}$ retaining over $90 \%$ of the initial efficiency when bent with radii below $8 \mathrm{~mm}$. Furthermore, we carried out multiple-cycles bending tests, the devices exhibit promising mechanical stability, being able to retain more than $90 \%$ and $88 \%$ of the original efficiency after 300 bending cycles at $10 \mathrm{~mm}$ and $6 \mathrm{~mm}$ bending radius, respectively (see Fig. S8b, ESI $\dagger$ ). The bending tests are carried out using a Vernier caliper to define the curvature radius according to methods reported elsewhere. $\stackrel{12}{ }$ It is well known from literature, $, \underline{18}, \underline{51}, \underline{52}$ that the device performance degradation after repeated mechanical bending is mainly originating from increased series resistance due to formation of fractures and cracks perpendicular to the bending direction in the brittle TCO layer. Different studies suggest promising alternatives to brittle TCO films, 
such as highly bendable silver-mesh/conducting polymer substrates, $\underline{53}$ highly conductive poly(ethylenedioxythiophene):poly(styrene sulphonate) (PEDOT:PSS) ${ }^{54}$ and graphene. ${ }^{7}$

Nevertheless, these approaches result in device performances still far behind the ones obtained with TCO either due to higher parasitic absorption or lower conductivity. For this reason, highly bendable hybrid metal-mesh/TCO electrodes are currently in development. It should be noted that for realistic applications small radius of curvature below $10 \mathrm{~cm}$ are unlikely.

For the development of 4-terminal tandem solar cells, each sub-cell is grown on flexible substrates: perovskite cells with a low temperature process on the front sheet and the CIGS solar cells on polyimide. For application in tandem devices he perovskite top cell requires a near infrared (NIR) transparent back electrode to guarantee low energy photons to reach the CIGS bottom cell. We deposited $40 \mathrm{~nm}$ of $\mathrm{MoO}_{3}$ by thermal evaporation as buffer layer to protect the underlying Spiro-OMeTAD and perovskite films from possible damages during sputtering of the back transparent electrode. A high-mobility transparent $\operatorname{In}_{2} \mathrm{O}_{3}: \mathrm{H}$ TCO $(\sim 180 \mathrm{~nm})$ was deposited by radio-frequency magnetron sputtering..$^{24}$ The cell size $\left(0.285 \mathrm{~cm}^{2}\right)$ is defined by mechanical scribing down to the AZO contact. Fig. 5a and b show the schematic of the NIR-transparent flexible perovskite solar cell and the SEM cross section of the device. The solar cell exhibits an average transmittance of $78 \%$ between $800-1000 \mathrm{~nm}$ (Fig. 5c). No deviation between forward and backward $J-V$ scans is observed. The device shows $V_{\mathrm{OC}}$ of $1.08 \mathrm{~V}, J \mathrm{sc}$ of $16.1 \mathrm{~mA} / \mathrm{cm}^{2}$, FF of $68.5 \%$, yielding an efficiency of $11.9 \%$ (Fig. $5 \mathrm{c}$ ). The cell reaches a steady-state efficiency of $12.2 \%$ with $J_{\mathrm{MPP}}$ of $14.6 \mathrm{~mA} / \mathrm{cm}^{2}$ and $V_{\mathrm{MPP}}$ of $0.84 \mathrm{~V}$ (Fig. 5e) and the $J_{\mathrm{SC}}$ value obtained by the EQE spectrum is equal to $16 \mathrm{~mA} / \mathrm{cm}^{2}$ (Fig. $5 \mathrm{f}$ ).

Fig. S9 (ESI†) shows the schematic architecture of the 4-terminal flexible tandem cell, the $J-V$ characteristics and EQE spectra of the standalone single sub-cells are shown in Fig. 6a and b. The CIGS bottom cell was grown on polyimide substrate according to processes described by Chirila 
et al.. ${ }^{2}, \underline{55}$ The efficiency of the flexible CIGS solar cell is $17.7 \%$ under AM1.5G illumination and $6 \%$ when measured with an NIR-transparent flexible perovskite solar cell applied as filter. The cell area of the bottom CIGS is defined by a laser-scribed shadow mask with an aperture of $0.213 \mathrm{~cm}^{2}$ inserted between the top and bottom sub-cells. ${ }^{29}$ The photovoltaic performances and parameters are summarized in Table 1 . The combination of the sub-cells to a 4-terminal flexible perovskite/CIGS device yields $18.2 \%$ efficiency.

This first proof of concept is established and the main losses in the device can be identified: the $J_{\text {sc }}$ of the perovskite top cell can be significantly improved by increasing the perovskite absorber layer thickness; a higher FF is expected by reduction of ohmic losses (series resistance) through better contacts design. The $V_{\mathrm{OC}}$ can be enhanced by improving interfaces between the absorber and charge selective layers. To achieve higher tandem solar cell performances, reduction of absorption losses in TCOs and wider band gap perovskite absorbers are needed.

\section{Conclusion}

We have demonstrated flexible perovskite solar cells with steady-state efficiencies above $13 \%$ directly grown with a low temperature process on a flexible front sheet which is used as efficient encapsulation material in flexible CIGS solar modules. The use of vacuum-based deposition processes for the electron transport multilayer and $\mathrm{PbI}_{2}$ perovskite precursor layer enables uniform layer growth. Flexible perovskite solar cells are achieved with an efficiency of $10.9 \%$ on an area above $1 \mathrm{~cm}^{2}$. The opaque gold electrode is substituted with high mobility $\operatorname{In}_{2} \mathrm{O}_{3}: \mathrm{H}$ to realize NIR-transparent flexible perovskite solar cells with stabilized efficiencies up to $12.2 \%$. These devices are used for flexible all-thin-film tandem solar cells. It is important to bear in mind the cost saving by growing the NIR-transparent perovskite solar cell directly on the encapsulation front sheet; its multi-functionality avoids any additional costs for the top cell substrate. We have demonstrated flexible thin-film 4-terminal perovskite/CIGS tandem solar cell with efficiencies 
above $18 \%$, better than both the single junction devices employed. NIR-transparent flexible perovskite solar cells lay the foundation for high efficiency polycrystalline all-thin-film flexible tandem devices with CIGS bottom cells. The deposition processes are suitable for roll-to-roll manufacturing in future.

\section{Methods}

\section{Device fabrication}

Perovskite solar cells are grown on flexible foil which is used as moisture barrier front sheet for encapsulation in flexible CIGS modules. $5 \mathrm{~cm} \times 5 \mathrm{~cm}$ size flexible substrates are washed by hand followed by ultrasonic soap and water baths. The substrates are dried in vacuum and cut into 4 quarters. Prior to further processing, $400 \mathrm{~nm}$ of compact $\mathrm{ZnO}: \mathrm{Al}$ layer is deposited at room temperature by $\mathrm{RF}$ sputtering from a ceramic $\mathrm{ZnO}$ target (containing $2 \mathrm{wt} \% \mathrm{Al}_{2} \mathrm{O}_{3}$ ) using the following parameters: $3 \mathrm{~W} \mathrm{~cm}$ power density, $\mathrm{Ar}$ and $\mathrm{Ar} / \mathrm{O}_{2}\left(3 \mathrm{~mol} \% \mathrm{O}_{2}\right)$ flow of $3.2 \times 10^{-2} \mathrm{~Pa}$ $\mathrm{m}^{3} \mathrm{~s}^{-1}$ and $4.6 \times 10^{-4} \mathrm{~Pa} \mathrm{~m}^{3} \mathrm{~s}^{-1}$, respectively. The sheet resistance of as-deposited film on glass is around $30 \Omega_{\square}$ measured by 4-probe method. $50 \mathrm{~nm}$ of compact $\mathrm{ZnO}$ layer is deposited at roomtemperature by radio-frequency $(\mathrm{RF})$ sputtering on top of the Flexible substrate/AZO using the

following parameters: $2.5 \mathrm{~W} \mathrm{~cm}^{-2}$ power density, $\mathrm{Ar}$ and $\mathrm{Ar} / \mathrm{O}_{2}\left(3 \mathrm{~mol} \% \mathrm{O}_{2}\right)$ flow of $7.2 \times 10^{-2} \mathrm{~Pa}$ $\mathrm{m}^{3} \mathrm{~s}^{-1}$ and $2.6 \times 10^{-2} \mathrm{~Pa} \mathrm{~m}^{3} \mathrm{~s}^{-1}$, respectively. Then, $7.5 \mathrm{~nm}$ of $\mathrm{C} 60$ is thermally evaporated in a $\mathrm{N}_{2}$ filled glove-box on top of Flexible substrate/AZO/ZnO. In order to compare evaporated $\mathrm{C} 60$ with spin coated PCBM, $100 \mu \mathrm{L}$ of PCBM solution in chlorobenzene are spin coated on top of $\mathrm{ZnO}$ at $2000 \mathrm{rpm}, 2000 \mathrm{rpm} \mathrm{s}^{-1}$, for $45 \mathrm{~s}$. The $\mathrm{PbI}_{2}$ film is thermally evaporated on rotating Flexible substrate/AZO/ZnO/C60 at a deposition pressure of 2-6 $\times 10^{-6} \mathrm{~Pa}$. The deposition rate is controlled within 1.2-1.6 $\AA^{-1}$, monitored by a quartz crystal microbalance. The thickness of $\mathrm{PbI}_{2}$ is $140 \mathrm{~nm}$. After the $\mathrm{PbI}_{2}$ deposition, the samples are subsequently transferred into a $\mathrm{N}_{2}$ filled glove-box for further processing. The perovskite layer is formed by spin coating of $\mathrm{CH}_{3} \mathrm{NH}_{3} \mathrm{I}$ in 
2-propanol at a concentration of $50 \mathrm{mg} \mathrm{mL}^{-1}$. The solution is first spread to cover the whole substrate, and wait for $5 \mathrm{~s}$ before starting the rotation $\left(4000 \mathrm{rpm}, 4000 \mathrm{rpm} \mathrm{s}^{-1}\right.$ for $\left.40 \mathrm{~s}\right)$. The asprepared films are annealed at $50{ }^{\circ} \mathrm{C}$ for $1 \mathrm{~h}$ on a hotplate inside the glovebox. After annealing, the samples are cooled down to room temperature and $100 \mu \mathrm{L}$ of a Spiro-OMeTAD solution (78.2 mg 2,2',7,7'-tetrakis-(N,N'-di-p-methoxyphenylamine)-9,9'-spirobifluorene (SpiroOMeTAD), $33 \mu \mathrm{L}$ lithium-bis(trifluoromethanesulfonyl)imide (Li-TFSI) solution (170 mg LiTFSI in $1 \mathrm{~mL}$ acetonitrile, Sigma-Aldrich), and 8.2 $\mu \mathrm{L}$ 4-tertbutylpyridine (TBP) all dissolved in $1 \mathrm{~mL}$ of chlorobenzene (Sigma-Aldrich) is spin coated on top of perovskite at $2500 \mathrm{rpm}, 2500$ $\mathrm{rpm} \mathrm{s}^{-1}$ for $45 \mathrm{~s}$. The devices are finished by evaporating $50 \mathrm{~nm}$ Au through a metal mask under high vacuum $\left(<3 \times 10^{-4} \mathrm{~Pa}\right)$. For NIR-transparent device, a $40 \mathrm{~nm}$ thick $\mathrm{MoO}_{3}$ is deposited on top of Spiro-OMeTAD via thermal evaporation, which is covered by $180 \mathrm{~nm}$ of $\operatorname{In}_{2} \mathrm{O}_{3}: \mathrm{H}$ as transparent electrode. Ni/Al grids with $50 \mathrm{~nm} / 4000 \mathrm{~nm}$ thickness are deposited by e-beam evaporation. The solar cell area is defined by mechanical scribing.

\section{Characterization}

The current density-voltage characteristics of perovskite solar cells are measured under standard simulated AM1.5G illumination using a Keithley 2400 source meter. The illumination intensity is calibrated to $1000 \mathrm{~W} \mathrm{~m}^{-2}$ using a certified single crystalline silicon solar cell. The $J-V$ measurement is performed in both forward (form $-0.1 \mathrm{~V}$ to $1.4 \mathrm{~V}$ ) and backward (from $1.4 \mathrm{~V}$ to $0.1 \mathrm{~V}$ ) direction separately without any pretreatment (e.g., light soaking, holding at forward bias for certain time etc.). The scan rate and delay time are $0.3 \mathrm{~V} \mathrm{~s}^{-1}$ and $10 \mathrm{~ms}$, respectively. The external quantum efficiency is measured with a lock-in amplifier. The probing beam is generated by a chopped white source $(900 \mathrm{~W}$, halogen lamp, $260 \mathrm{~Hz})$ and a dual grating monochromator. The beam size is adjusted to ensure that the illumination area is fully inside the cell area. A 
certified single crystalline silicon solar cell is used as the reference cell. White light bias is applied during the measurement with $\sim 0.1$ sun intensity. The steady-state efficiency as a function of time is recorded using a maximum power point tracker, which adjusts the applied voltage in order to reach the maximum power point (perturb and observe algorithm). The starting voltage is set to be $0.1 \mathrm{~V}$.

\section{Acknowledgements}

Financial funding from Swiss National Science Foundation (SNF)-NRP70, PV2050 (project NO.: 407040_153976 and 407040_153916), SNF-NanoTera and Swiss Federal Office of Energy (SYNERGY: 20NA21_150950), NanoTera (project Synergy Gateway) and FP7 APPOLO project (609355). We acknowledge access to the Scanning Probe Microscopy User Lab at Empa for the (AFM) measurements. 


\section{References}

Bibliography

1. P. Reinhard, A. Chirila, P. Blosch, F. Pianezzi, S. Nishiwaki, S. Buecheler and A. N. Tiwari, Ieee J Photovolt, 2013, 3, 572-580.

2. A. Chirila, P. Reinhard, F. Pianezzi, P. Bloesch, A. R. Uhl, C. Fella, L. Kranz, D. Keller, C. Gretener, H. Hagendorfer, D. Jaeger, R. Erni, S. Nishiwaki, S. Buecheler and A. N. Tiwari, Nat Mater, 2013, 12, 1107-1111.

3. NREL Efficiency Chart, http://www.nrel.gov/pv/assets/images/efficiency_chart.jpg).

4. P. Docampo, J. M. Ball, M. Darwich, G. E. Eperon and H. J. Snaith, Nature Communications, 2013, 4.

5. Y. M. Wang, S. Bai, L. Cheng, N. N. Wang, J. P. Wang, F. Gao and W. Huang, Advanced Materials, 2016, 28, 4532-4540.

6. F. Di Giacomo, A. Fakharuddin, R. Jose and T. M. Brown, Energ Environ Sci, 2016, 9, 3007-3035.

7. J. Yoon, H. Sung, G. Lee, W. Cho, N. Ahn, H. S. Jung and M. Choi, Energ Environ Sci, 2016.

8. V. Zardetto, T. M. Brown, A. Reale and A. Di Carlo, J Polym Sci Pol Phys, 2011, 49, 638-648.

9. X. T. Yin, P. Chen, M. D. Que, Y. L. Xing, W. X. Que, C. M. Niu and J. Y. Shao, ACS Nano, 2016, 10, 3630-3636.

10. H. Zhang, J. Q. Cheng, F. Lin, H. X. He, J. Mao, K. S. Wong, A. K. Y. Jen and W. C. H. Choy, ACS Nano, 2016, 10, 1503-1511. 
11. J. W. Jo, M. S. Seo, M. Park, J. Y. Kim, J. S. Park, I. K. Han, H. Ahn, J. W. Jung, B. H. Sohn, M. J. Ko and H. J. Son, Adv Funct Mater, 2016, 26, 4464-4471.

12. D. Yang, R. X. Yang, X. D. Ren, X. J. Zhu, Z. Yang, C. Li and S. Z. Liu, Advanced Materials, 2016, 28, 5206-+.

13. H. Yoon, S. M. Kang, J. K. Lee and M. Choi, Energ Environ Sci, 2016, 9, 2262-2266.

14. C. L. Wang, D. W. Zhao, C. R. Grice, W. Q. Liao, Y. Yu, A. Cimaroli, N. Shrestha, P. J. Roland, J. Chen, Z. H. Yu, P. Liu, N. Cheng, R. J. Ellingson, X. Z. Zhao and Y. F. Yan, J Mater Chem A, 2016, 4, 12080-12087.

15. M. Park, J. S. Park, I. Han and J. Y. Oh, J Mater Chem A, 2016, 4, 11307-11316.

16. J. H. Heo, M. H. Lee, H. J. Han, B. R. Patil, J. S. Yu and S. H. Im, J Mater Chem A, 2016, 4, 1572-1578.

17. S. S. Shin, W. S. Yang, E. J. Yeom, S. J. Lee, N. J. Jeon, Y. C. Joo, I. J. Park, J. H. Noh and S. I. Seok, J Phys Chem Lett, 2016, 7, 1845-1851.

18. B. J. Kim, D. H. Kim, Y. Y. Lee, H. W. Shin, G. S. Han, J. S. Hong, K. Mahmood, T. K. Ahn, Y. C. Joo, K. S. Hong, N. G. Park, S. Lee and H. S. Jung, Energ Environ Sci, 2015, 8, 916921.

19. S. N. Habisreutinger, D. P. McMeekin, H. J. Snaith and R. J. Nicholas, Apl Mater, 2016, 4.

20. X. Y. Zhao, H. P. Shen, Y. Zhang, X. Li, X. C. Zhao, M. Q. Tai, J. F. Li, J. B. Li, X. Li and H. Lin, Acs Appl Mater Inter, 2016, 8, 7826-7833.

21. B. Roose, J.-P. C. Baena, K. C. Gödel, M. Graetzel, A. Hagfeldt, U. Steiner and A. Abate, Nano Energy, 2016, 30, 517-522. 
22. C. Roldan-Carmona, O. Malinkiewicz, A. Soriano, G. M. Espallargas, A. Garcia, P.

Reinecke, T. Kroyer, M. I. Dar, M. K. Nazeeruddin and H. J. Bolink, Energ Environ Sci, 2014, 7, 994-997.

23. C. D. Bailie and M. D. McGehee, Mrs Bull, 2015, 40, 681-685.

24. F. Fu, T. Feurer, T. Jager, E. Avancini, B. Bissig, S. Yoon, S. Buecheler and A. N. Tiwari, Nature Communications, 2015, 6.

25. C. D. Bailie, M. G. Christoforo, J. P. Mailoa, A. R. Bowring, E. L. Unger, W. H. Nguyen, J. Burschka, N. Pellet, J. Z. Lee, M. Gratzel, R. Noufi, T. Buonassisi, A. Salleo and M. D. McGehee, Energ Environ Sci, 2015, 8, 956-963.

26. K. A. Bush, C. D. Bailie, Y. Chen, A. R. Bowring, W. Wang, W. Ma, T. Leijtens, F. Moghadam and M. D. McGehee, Advanced Materials, 2016, 28, 3937-+.

27. J. Werner, L. Barraud, A. Walter, M. Bräuninger, F. Sahli, D. Sacchetto, N. Tétreault, B. Paviet-Salomon, S.-J. Moon, C. Allebé, M. Despeisse, S. Nicolay, S. De Wolf, B. Niesen and C. Ballif, ACS Energy Letters, 2016, 1, 474-480.

28. J. Werner, C. H. Weng, A. Walter, L. Fesquet, J. P. Seif, S. De Wolf, B. Niesen and C. Ballif, J Phys Chem Lett, 2016, 7, 161-166.

29. L. Kranz, A. Abate, T. Feurer, F. Fu, E. Avancini, J. Lockinger, P. Reinhard, S. M. Zakeeruddin, M. Gratzel, S. Buecheler and A. N. Tiwari, J Phys Chem Lett, 2015, 6, 2676-2681. 30. D. P. McMeekin, G. Sadoughi, W. Rehman, G. E. Eperon, M. Saliba, M. T. Horantner, A. Haghighirad, N. Sakai, L. Korte, B. Rech, M. B. Johnston, L. M. Herz and H. J. Snaith, Science, 2016, 351, 151-155.

31. S. Albrecht, M. Saliba, J. P. C. Baena, F. Lang, L. Kegelmann, M. Mews, L. Steier, A. Abate, J. Rappich, L. Korte, R. Schlatmann, M. K. Nazeeruddin, A. Hagfeldt, M. Gratzel and B. Rech, Energ Environ Sci, 2016, 9, 81-88. 
32. B. Chen, Y. Bai, Z. S. Yu, T. Li, X. P. Zheng, Q. F. Dong, L. Shen, M. Boccard, A. Gruverman, Z. Holman and J. S. Huang, Adv Energy Mater, 2016, 6.

33. T. Todorov, O. Gunawan and S. Guha, Molecular Systems Design \& Engineering, 2016, 1, 370-376.

34. J. Peng, T. Duong, X. Zhou, H. Shen, Y. Wu, H. K. Mulmudi, Y. Wan, D. Zhong, J. Li, T. Tsuzuki, K. J. Weber, K. R. Catchpole and T. P. White, Adv Energy Mater, 2016, 1601768n/a.

35. F. Fu, T. Feurer, T. P. Weiss, S. Pisoni, E. Avancini, C. Andres, S. Buecheler and A. N. Tiwari, Nature Energy, 2016, 2, 16190.

36. W. Zhang, M. Saliba, D. T. Moore, S. K. Pathak, M. T. Horantner, T. Stergiopoulos, S. D. Stranks, G. E. Eperon, J. A. Alexander-Webber, A. Abate, A. Sadhanala, S. H. Yao, Y. L. Chen, R. H. Friend, L. A. Estroff, U. Wiesner and H. J. Snaith, Nature Communications, 2015, 6.

37. W. J. Ke, D. W. Zhao, C. R. Grice, A. J. Cimaroli, J. Ge, H. Tao, H. W. Lei, G. J. Fang and Y. F. Yan, J Mater Chem A, 2015, 3, 17971-17976.

38. C. Momblona, L. Gil-Escrig, E. Bandiello, E. M. Hutter, M. Sessolo, K. Lederer, J. Blochwitz-Nimoth and H. J. Bolink, Energ Environ Sci, 2016, 9, 3456-3463.

39. P. W. Liang, C. C. Chueh, S. T. Williams and A. K. Y. Jen, Adv Energy Mater, 2015, 5.

40. K. Wojciechowski, T. Leijtens, S. Siprova, C. Schlueter, M. T. Horantner, J. T. W. Wang, C. Z. Li, A. K. Y. Jen, T. L. Lee and H. J. Snaith, J Phys Chem Lett, 2015, 6, 2399-2405.

41. D. W. Zhao, W. J. Ke, C. R. Grice, A. J. Cimaroli, X. X. Tan, M. J. Yang, R. W. Collins, H. M. Zhang, K. Zhu and Y. F. Yan, Nano Energy, 2016, 19, 88-97.

42. H. J. Snaith, A. Abate, J. M. Ball, G. E. Eperon, T. Leijtens, N. K. Noel, S. D. Stranks, J. T. W. Wang, K. Wojciechowski and W. Zhang, J Phys Chem Lett, 2014, 5, 1511-1515. 
43. E. L. Unger, E. T. Hoke, C. D. Bailie, W. H. Nguyen, A. R. Bowring, T. Heumuller, M. G. Christoforo and M. D. McGehee, Energ Environ Sci, 2014, 7, 3690-3698.

44. D. Bi, W. Tress, M. I. Dar, P. Gao, J. Luo, C. Renevier, K. Schenk, A. Abate, F.

Giordano, J. P. Correa Baena, J. D. Decoppet, S. M. Zakeeruddin, M. K. Nazeeruddin, M. Gratzel and A. Hagfeldt, Sci Adv, 2016, 2, e1501170.

45. A. Abrusci, S. D. Stranks, P. Docampo, H. L. Yip, A. K. Y. Jen and H. J. Snaith, Nano Lett, 2013, 13, 3124-3128.

46. F. Fu, L. Kranz, S. Yoon, J. Lockinger, T. Jager, J. Perrenoud, T. Feurer, C. Gretener, S. Buecheler and A. N. Tiwari, Phys Status Solidi A, 2015, 212, 2708-2717.

47. C. Roldan-Carmona, P. Gratia, I. Zimmermann, G. Grancini, P. Gao, M. Graetzel and M. K. Nazeeruddin, Energ Environ Sci, 2015, 8, 3550-3556.

48. Y. C. Kim, N. J. Jeon, J. H. Noh, W. S. Yang, J. Seo, J. S. Yun, A. Ho-Baillie, S. J.

Huang, M. A. Green, J. Seidel, T. K. Ahn and S. Il Seok, Adv Energy Mater, 2016, 6.

49. Y. L. Guo, W. Sato, K. Shoyama and E. Nakamura, J Am Chem Soc, 2016, 138, 54105416.

50. K. Jung, J. Lee, J. Kim, W. S. Chae and M. J. Lee, J Power Sources, 2016, 324, 142-149.

51. D. Y. Liu and T. L. Kelly, Nat Photonics, 2014, 8, 133-138.

52. K. Poorkazem, D. Y. Liu and T. L. Kelly, J Mater Chem A, 2015, 3, 9241-9248.

53. Y. W. Li, L. Meng, Y. Yang, G. Y. Xu, Z. R. Hong, Q. Chen, J. B. You, G. Li, Y. Yang and Y. F. Li, Nature Communications, 2016, 7.

54. M. Kaltenbrunner, G. Adam, E. D. Glowacki, M. Drack, R. Schwodiauer, L. Leonat, D. H. Apaydin, H. Groiss, M. C. Scharber, M. S. White, N. S. Sariciftci and S. Bauer, Nat Mater, 2015, 14, 1032-+. 
55. A. Chirila, S. Buecheler, F. Pianezzi, P. Bloesch, C. Gretener, A. R. Uhl, C. Fella, L. Kranz, J. Perrenoud, S. Seyrling, R. Verma, S. Nishiwaki, Y. E. Romanyuk, G. Bilger and A. N. Tiwari, Nat Mater, 2011, 10, 857-861. 
(a)

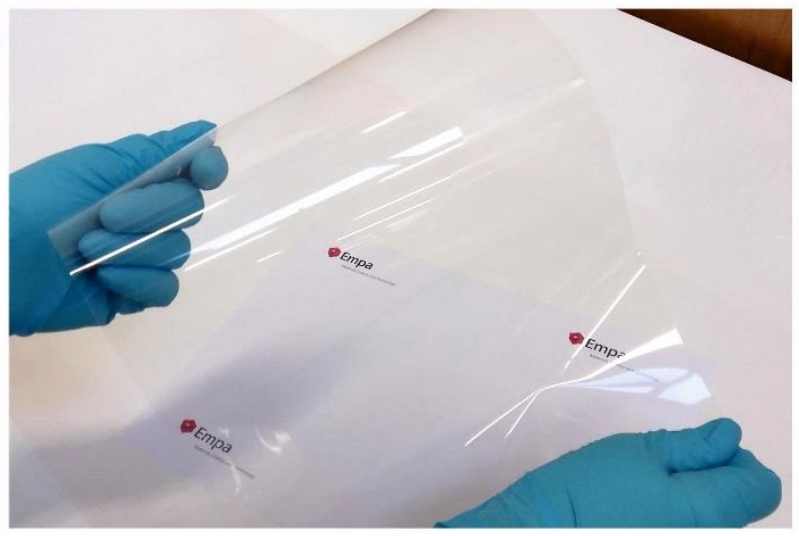

(c)

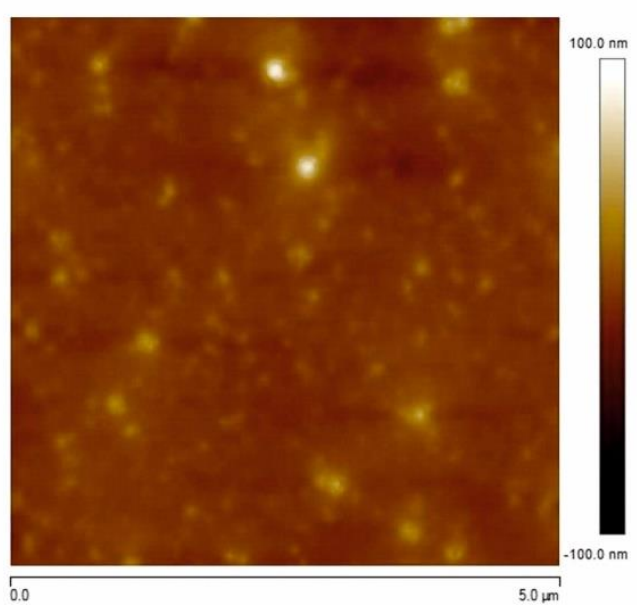

(b)

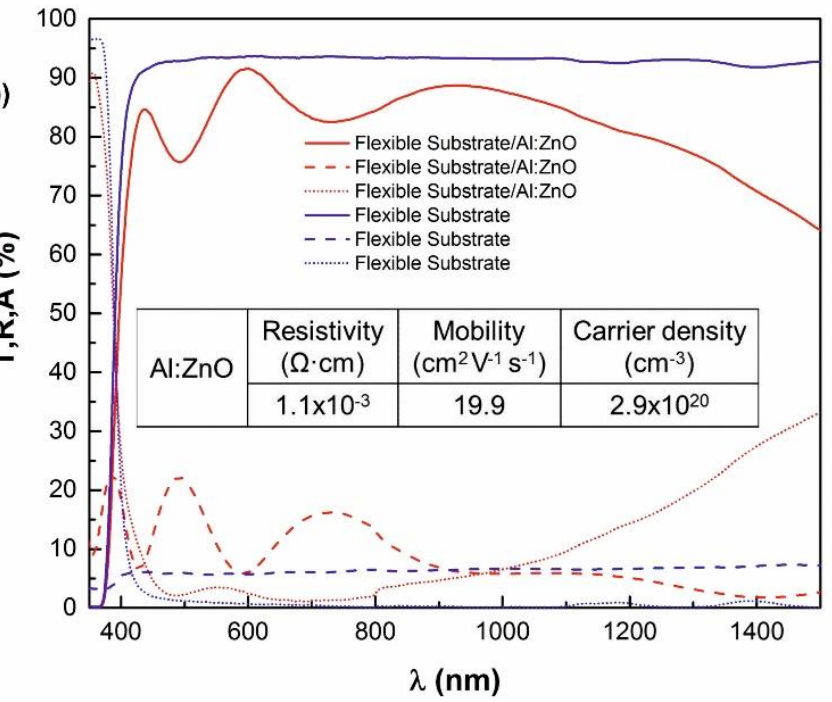

(d)

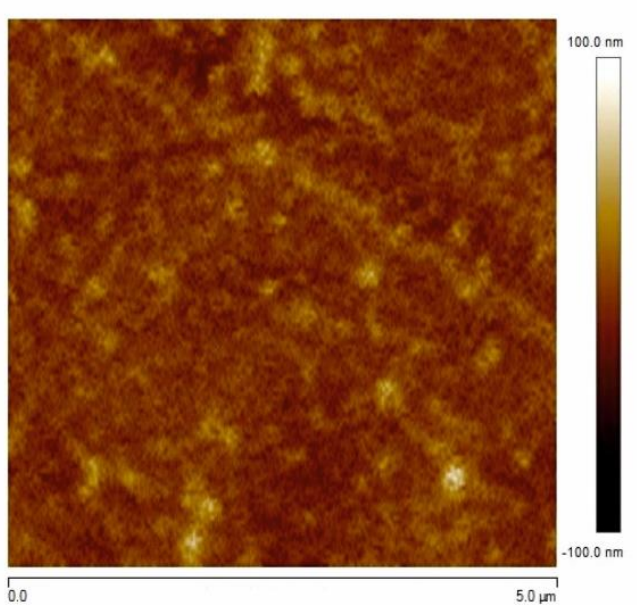

Fig. 1 (a) Photograph of flexible front sheet substrate without AZO layer. (b) Optical properties (Transmittance, solid lines, reflectance, dashed lines and absorptance, computed as 1-T-R, dotted lines) of the flexible substrate with (red lines) and without (blue lines) AZO layer, measured by absorption spectroscopy UV-vis-NIR. The inset shows the electrical properties of the AZO layer obtained by the Hall effect measurement. (c) AFM measurement of the flexible substrate surface, root mean square roughness of 7.4 nm. (d) AFM measurement of the AZO film deposited on top of the flexible substrate, root mean square roughness of $10.4 \mathrm{~nm}$. 


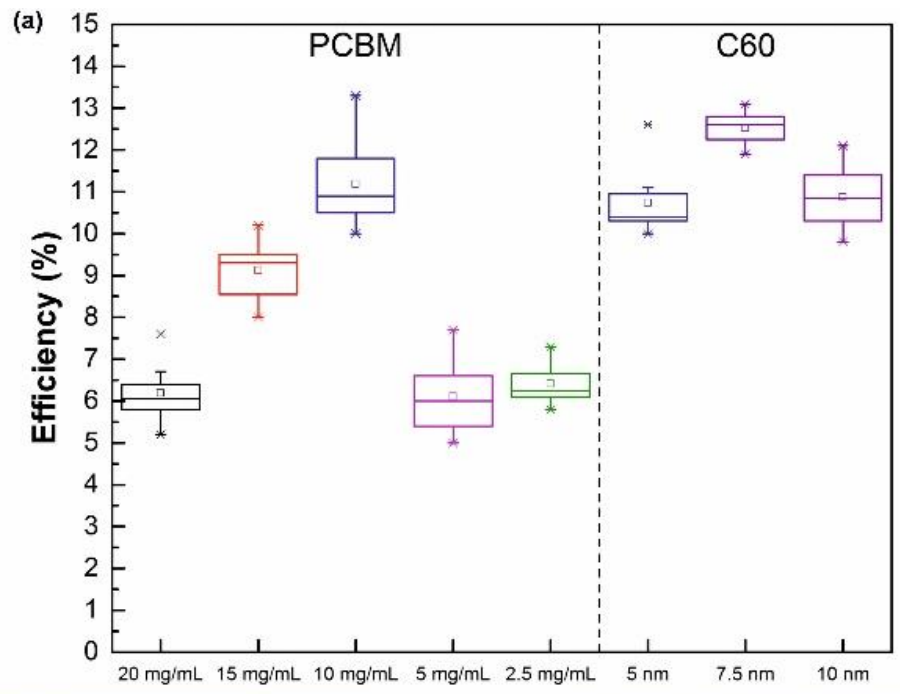

(b)

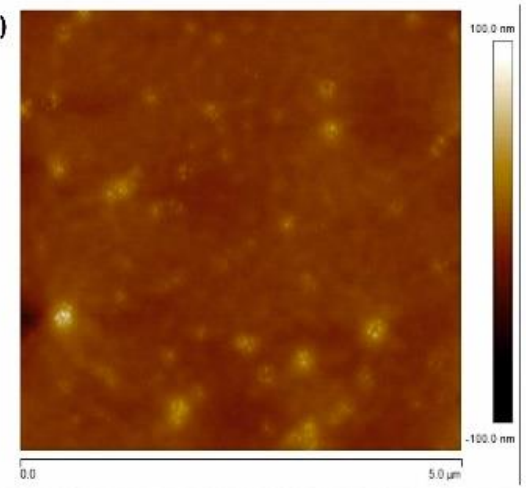

(d)

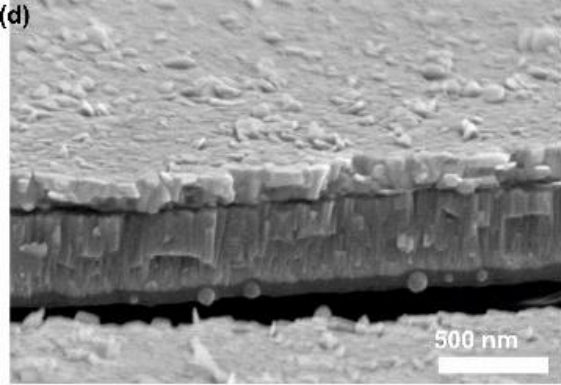

(c)

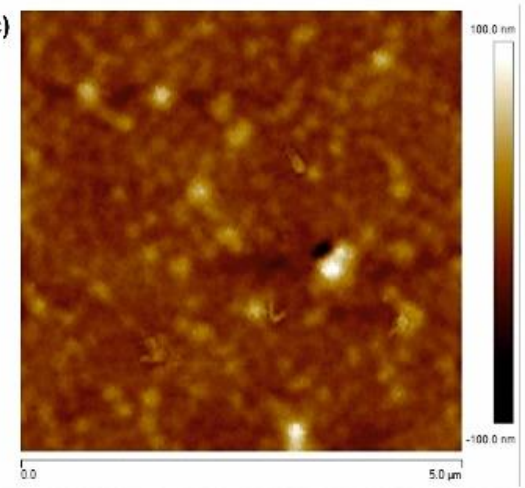

(e)

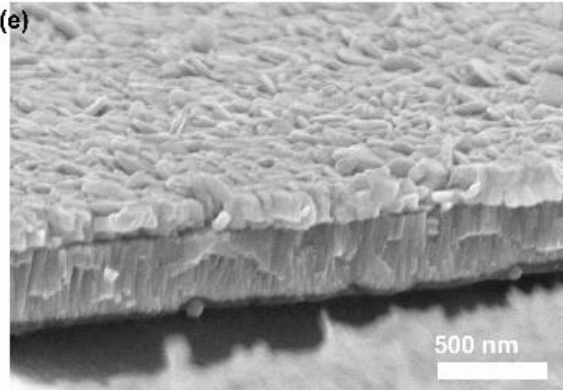

Fig. 2 (a) Comparison of efficiencies with five different PCBM concentrations in chlorobenzene (20,15, 10, 5 and $2.5 \mathrm{mg}$ $\mathrm{mL}^{-1}$ ) and three different thermally evaporated C60 thicknesses (5, 7.5 and $10 \mathrm{~nm}$ ). (b) AFM measurement of the ZnO surface coated with PCBM, root mean square roughness of $5.7 \mathrm{~nm}$. (c) AFM measurement of the ZnO surface coated with $\mathrm{C} 60$, root mean square roughness of $11.7 \mathrm{~nm}$. (d) Cross-sectional SEM image of $\mathrm{Pbl}_{2}$ deposited on PCBM layer. (e) Crosssectional SEM image of $\mathrm{Pbl}_{2}$ deposited on $\mathrm{C} 60$ layer. 
(a)

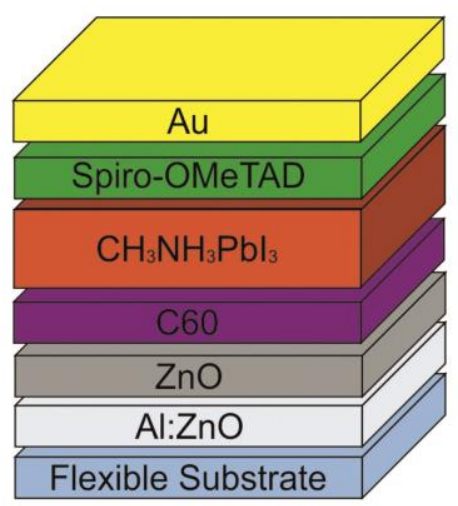

(c)

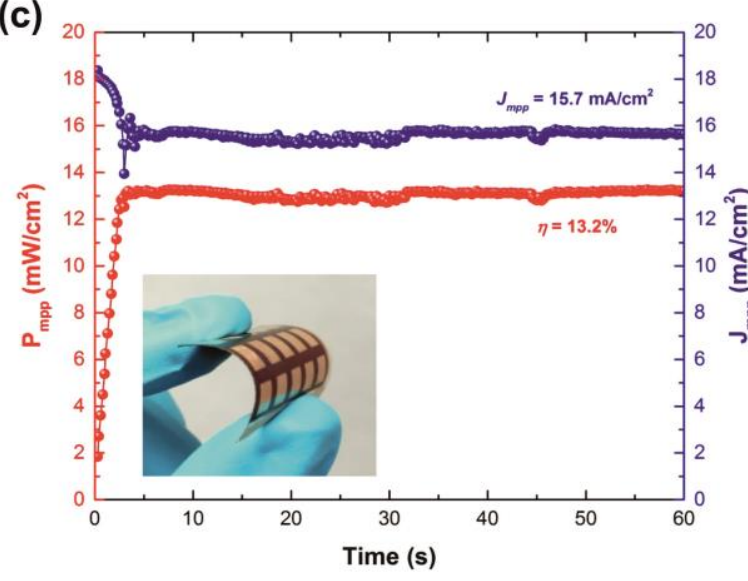

(b)

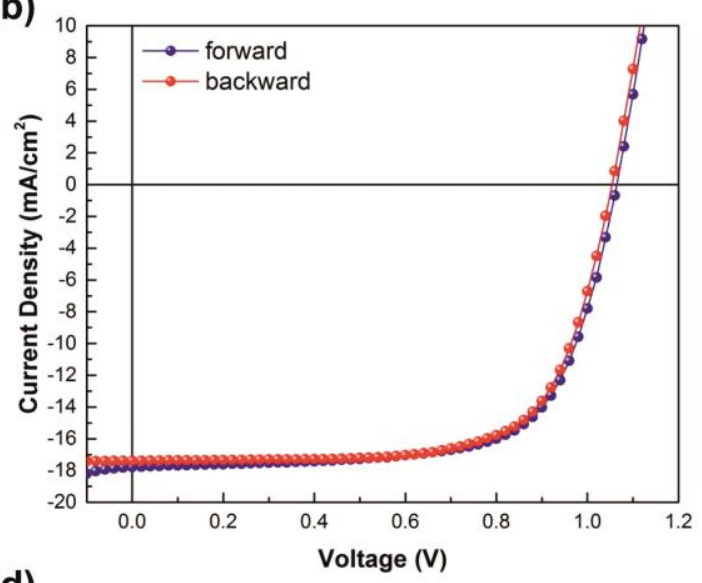

(d)

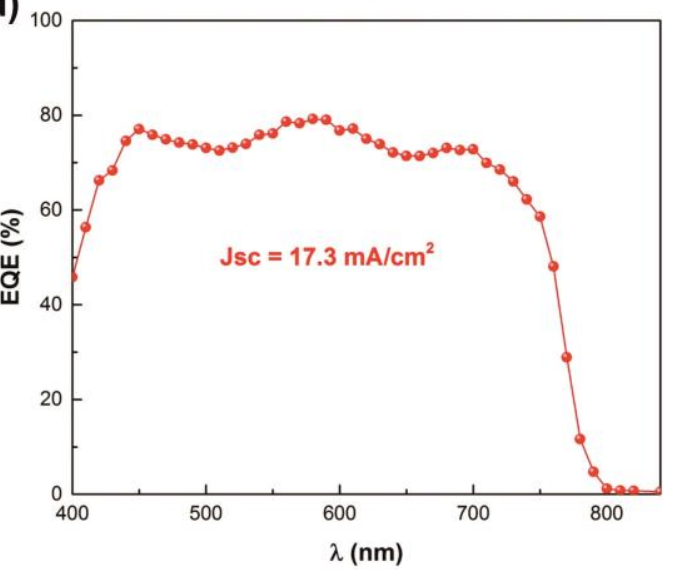

(e)

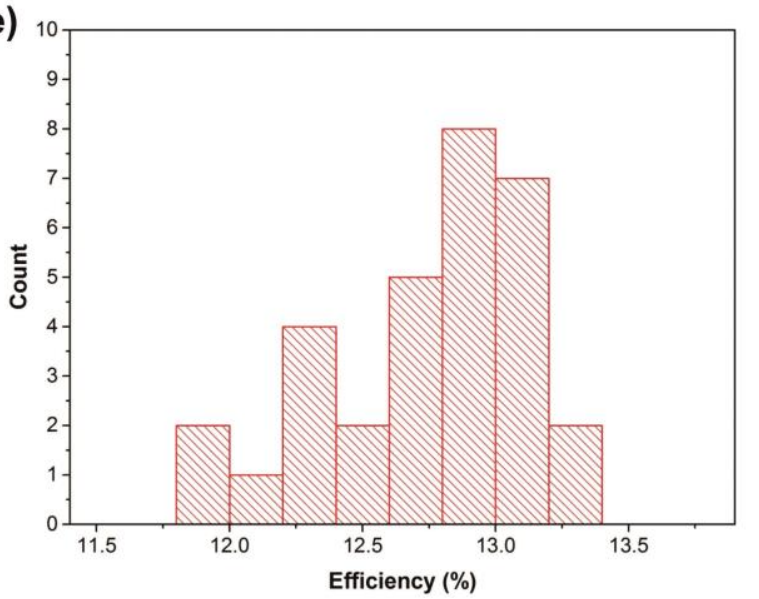

Fig. 3 (a) Schematic illustration of the $n-i-p$ planar heterojunction perovskite solar cell developed. (b) $J-V$ curves in forward (blue line), -0.1 $\mathrm{V}$ to $1.4 \mathrm{~V}$, and backward scan (red line), $1.4 \mathrm{~V}$ to $-0.1 \mathrm{~V}$, measured under standard test condition $\left(25^{\circ} \mathrm{C}\right.$, simulated $\left.\mathrm{AM} 1.5 \mathrm{G}, 1000 \mathrm{~W} / \mathrm{m}^{2}\right)$. (c) Steady-state output at MPP of the cell under continuous simulated AM1.5G one sun illumination. The inset shows a photograph of the champion flexible perovskite solar cell. (d) External quantum efficiency (EQE) spectrum. The calculated $J_{\mathrm{sc}}$ from EQE curve is $17.3 \mathrm{~mA} / \mathrm{cm}^{2}$. (e) Efficiency distribution histogram of more than 30 flexible perovskite solar cells $(12.7 \pm 0.36 \%)$. 
(a)

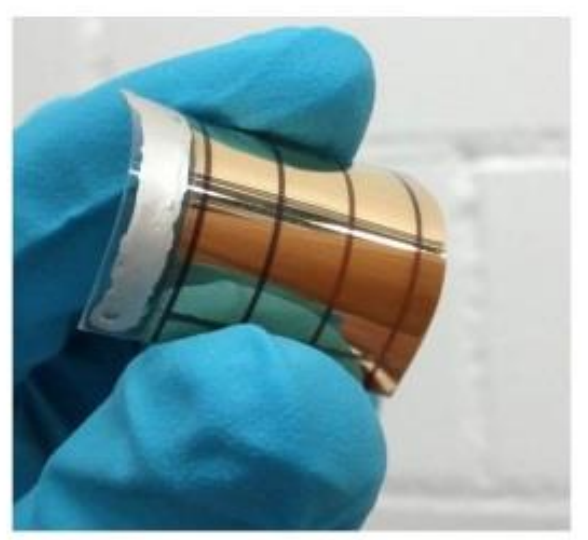

(c)

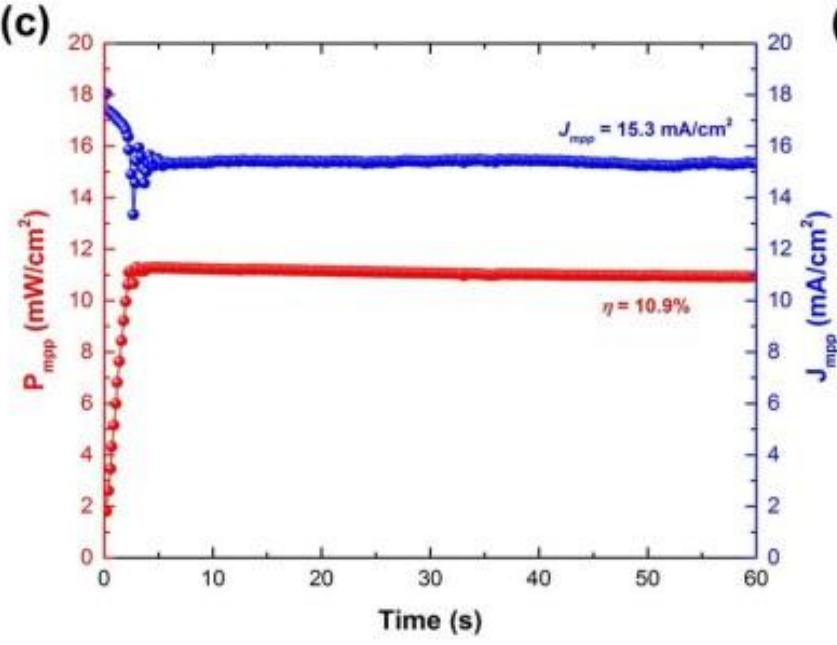

(b)

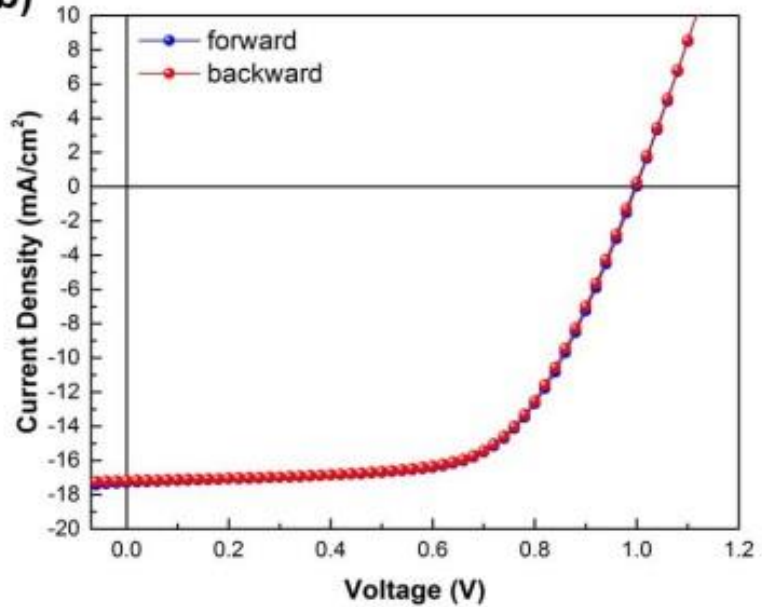

(d)

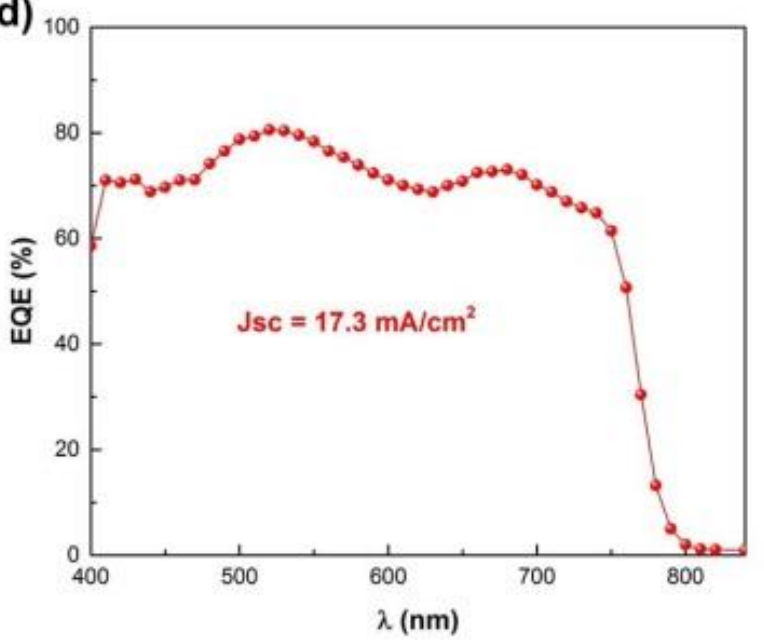

Fig. 4 (a) Photograph of the $1.03 \mathrm{~cm}^{2}$ flexible perovskite solar cell. $J-V$ curves (b) and steady-state output at MPP (c) of the corresponding $1.03 \mathrm{~cm}^{2}$ flexible solar cell under continuous simulated AM1.5G one sun illumination. (d) EQE spectrum. The calculated $J_{\mathrm{sc}}$ from EQE curve is $17.3 \mathrm{~mA} / \mathrm{cm}^{2}$. 
(a)

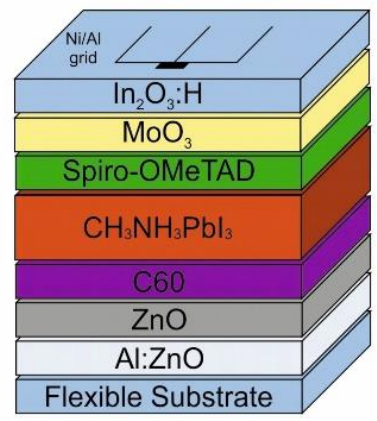

(d)

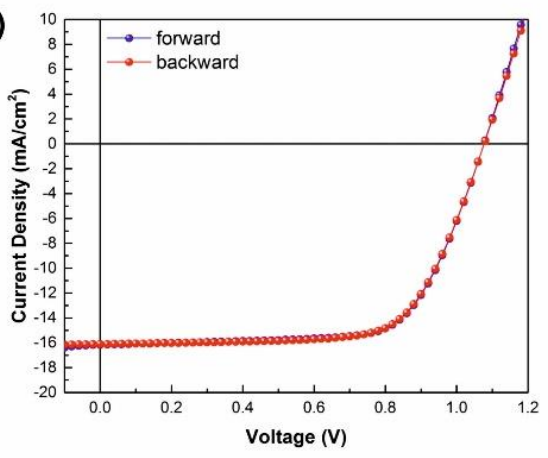

(b)

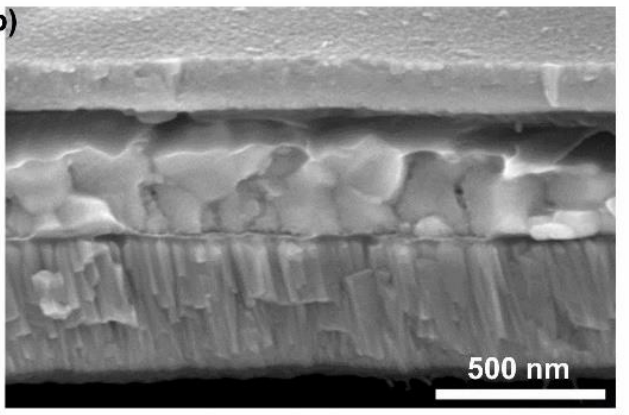

(e)

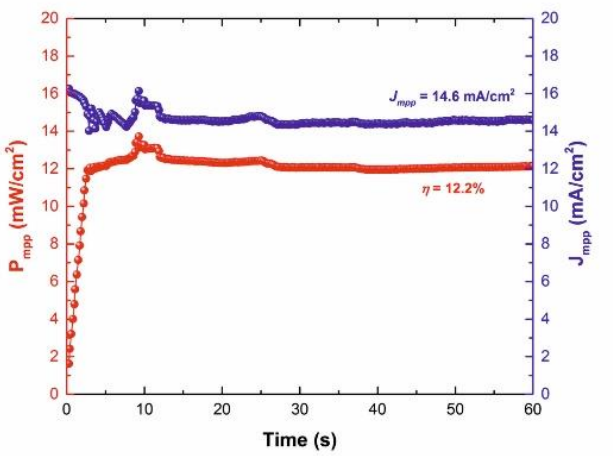

(c)

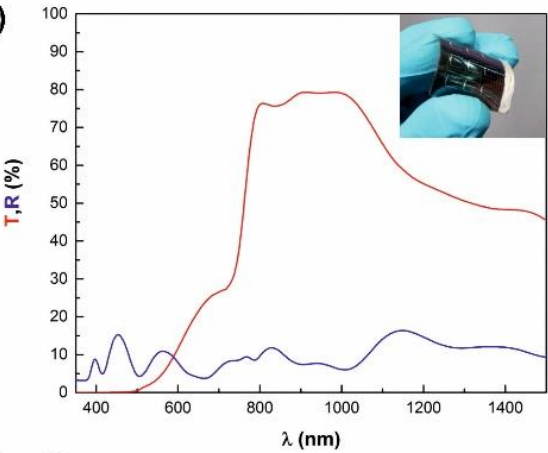

(f)

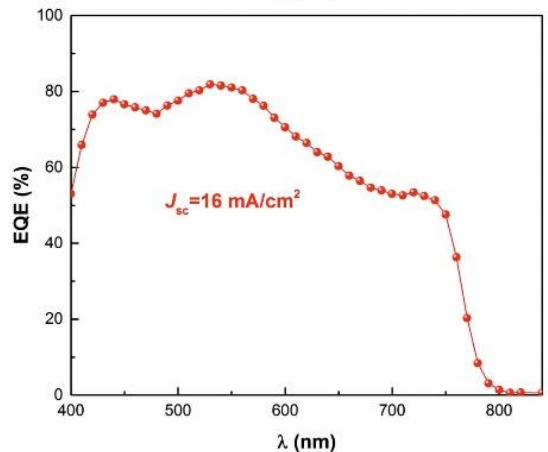

Fig. 5 (a) Schematic representation of the superstrate configuration flexible NIR-transparent perovskite solar cell. (b) Cross-sectional SEM image of the corresponding device. (c) Transmittance (red curve) and reflectance (blue curve) through the entire device stack, the inset shows a photograph of the bendable NIR-transparent cell. The average transmittance between $800-1000 \mathrm{~nm}$ is $78 \%$. (d,e) $J-V$ curves and steady-state output at MPP of the corresponding solar cell under continuous simulated AM1.5G one sun illumination. (f) EQE spectrum. The calculated $J_{\mathrm{SC}}$ from EQE curve is $16.0 \mathrm{~mA} / \mathrm{cm}^{2}$. 
(a)

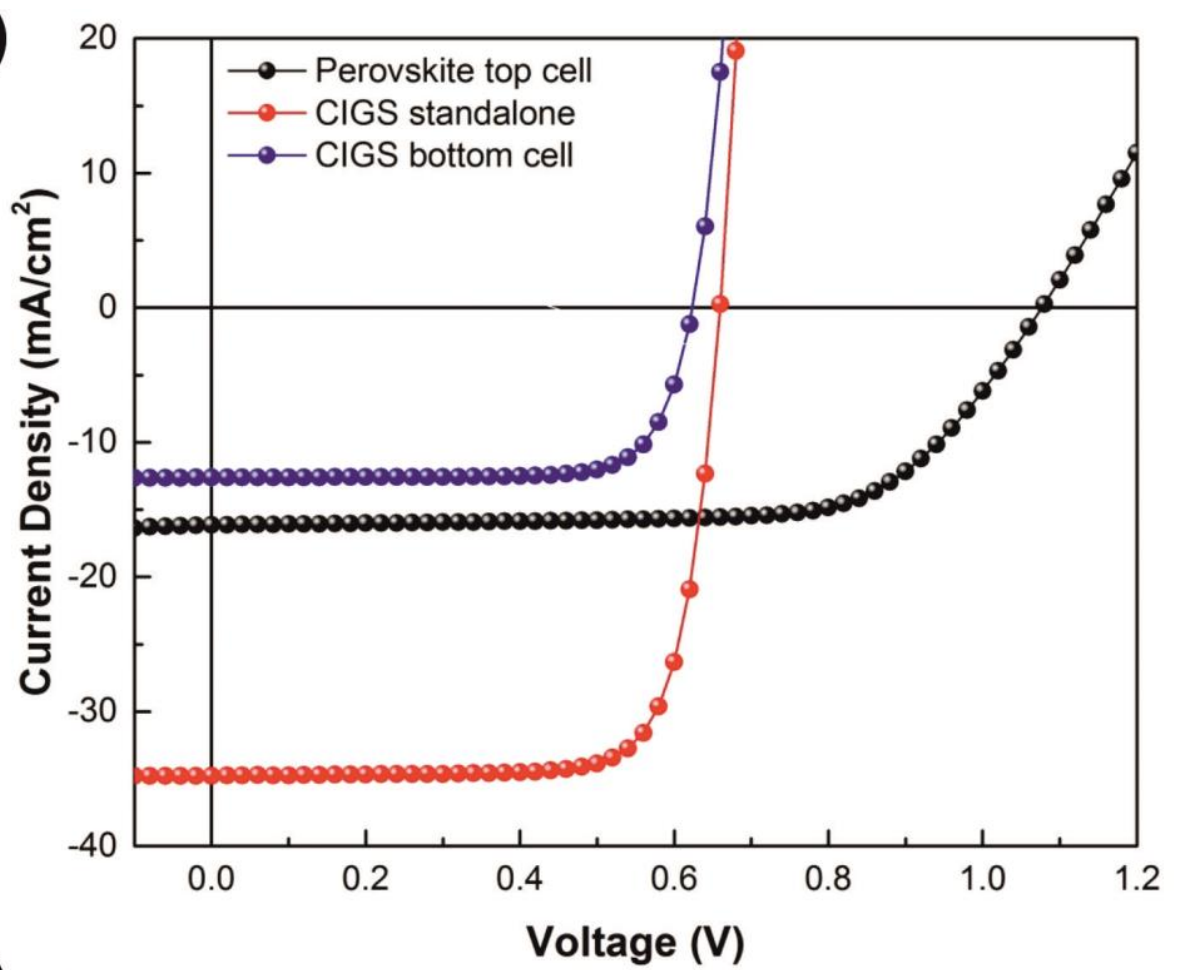

(b)

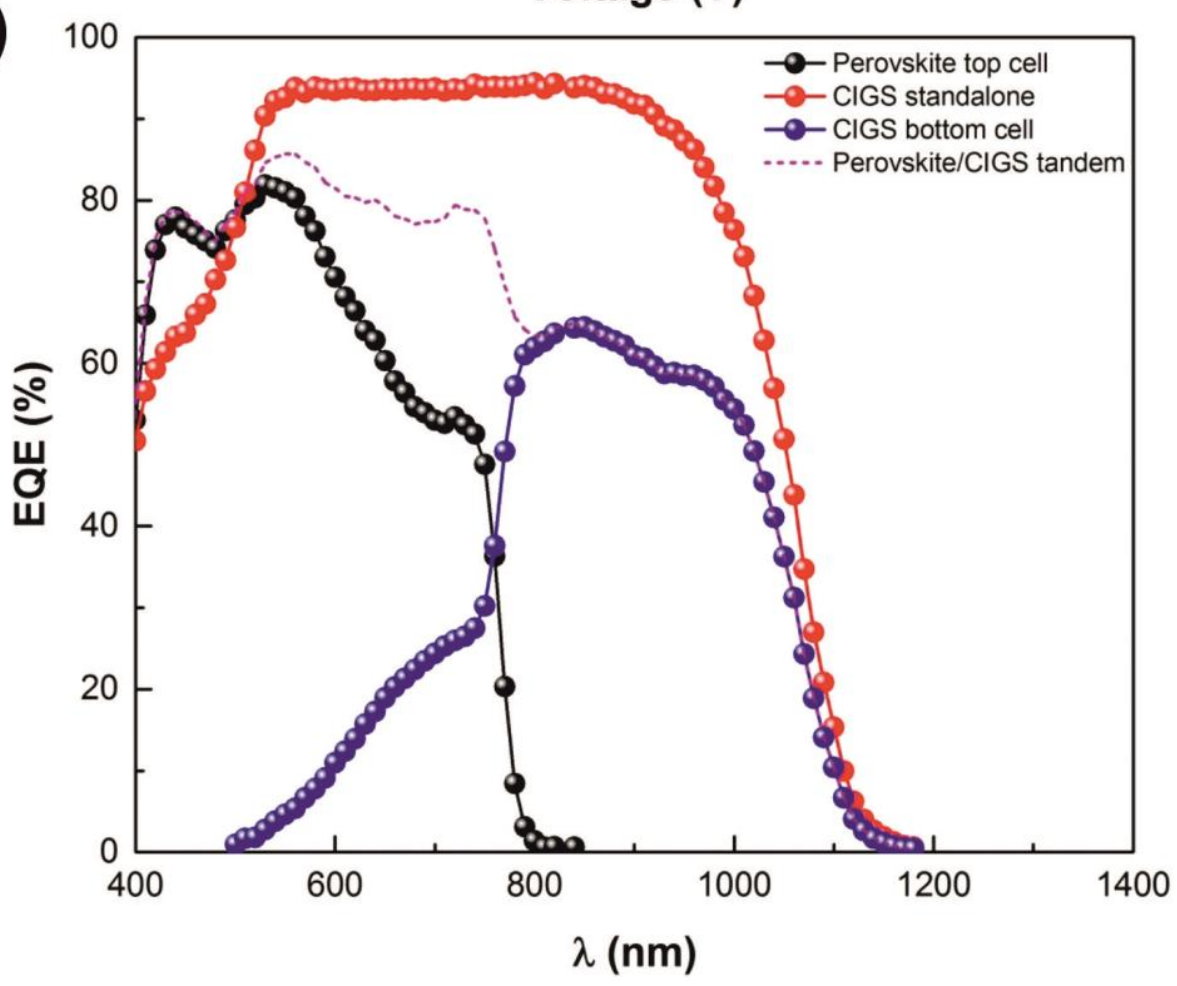

Fig. $6 \mathrm{~J}-V$ curves (a) and EQE spectra (b) of the flexible CIGS standalone cell (red curve), flexible CIGS bottom cell (blue curve) and flexible perovskite top cell (dark curve). The pink curve represents the perovskite-CIGS tandem spectrum. 
Table $1 \mathrm{~J}$-V parameters of the flexible sub-cells and tandem device. Starting from a standalone flexible CIGS with $17.7 \%$, we have achieved an $18.2 \%$ 4-terminal flexible perovskite/CIGS tandem.

\begin{tabular}{lcccccc}
\hline Solar Cell & $\boldsymbol{V}_{\text {oc }}(\mathbf{V})$ & $\boldsymbol{J}_{\mathbf{s c}}\left(\mathbf{m A} / \mathbf{c m}^{2}\right)$ & $\mathbf{F F}(\%)$ & $\boldsymbol{\eta}(\%)$ & $\boldsymbol{\eta}_{\mathbf{m p p}}(\%)$ & Cell area $\left(\mathbf{c m}^{2}\right)$ \\
\hline Flexible CIGS & 0.668 & 34.8 & 77.2 & 17.9 & 17.7 & 0.213 \\
Flexible CIGS bottom & & & & & & \\
cell & 0.632 & 12.6 & 77.3 & 6.1 & 6.0 & 0.213 \\
Flexible Perovskite top & 1.08 & 16.1 & 68.5 & 11.9 & 12.2 & 0.285 \\
cell & & & & & & \\
\hline
\end{tabular}

\section{Flexible}

Perovskite/CIGS 4-

18.2

Terminal Tandem 